\title{
Using Transition Systems to Formalise Ideas from Vedānta
}

\author{
Padmanabhan Krishnan \\ advaitagoldcoast@gmail.com
}

November 19, 2021

\begin{abstract}
Vedānta is one of the oldest philosophical systems. While there are many detailed commentaries on Vedānta, there are very few mathematical descriptions of the different concepts developed there. This article shows how ideas from theoretical computer science can be used to explain Vedānta. The standard idea of transition systems and modal logic are used to develop a formal description for the different ideas in Vedānta. The generality of the formalism is illustrated via a number of examples including saṃsāra, Patañjali's yoga sūtras, karma, the three avasthās from the Māndụkya Upaniṣad and the key difference between advaita and dvaita in relation to mokṣa.
\end{abstract}

\section{Motivation}

The Upaniṣads, also called Vedānta, [9, 25], move away from the purely ritualistic worship of God that is present in the earlier section of the Vedas. The Upanișads are viewed as one of the earliest philosophical texts and many of them pre-date Buddhist thought. These writings cover a variety of topics including the origins of the universe, what happens after death, what is the root cause of our experiences, and "Who am I?" or "What is my true self". They also wish to answer the question of what is eternally true what is changeable.

Because many of the Upanișads are terse, the core ideas in the Upanișads are expanded in different writings including detailed commentaries. These include, the Bhṛguvalli, [29, 21], the Pañcadas̄ì, [1], the Yoga-Vāsișțha, [2] and the Vivekacūạāmaṇi, [17]. More recent works (e.g., [31]) provide a highlevel summary of many of these concepts. They all explain the notion of 
Brahman, the ultimate entity who is above the Vedic Gods, as described in the Kena and other Upanișads, [4]. Technically, everything owes its existence to Brahman and Brahman is the sole "cause" of everything. In other words, if Brahman did not exist, nothing would exist. The writings also go on to argue that one's true self, i.e., the answer to the question "Who am I?" is related to Brahman. Many of the Upanisads also state that Brahman is not an object of knowledge. So Brahman cannot be known using conventional means of acquiring knowledge. Brahman is a pure subject that is the basis of all experiences, [6].

Explanations related to the universe and human existence is often based on karma or the law related to action and its consequences. Karma, in terms of the consequences that need to be bourne, is associated with an individual's jiva, which could be described as the individual's soul. It is the jiva that "carries" the karma. It is the presence of karma that leads to samsāra which is the cycle of birth and death. Mokșa, which is salvation or freedom from saṃsāra, is the aim of all spiritual seekers, [16]. Mokṣa is not only getting out of samsāra but it is also defined as being one with the divine. The different interpretations of Vedānta have slightly different definitions of being one with the divine. In Advaita one's true self is identical to Brahman. Therefore, mokșa (or salvation) in Advaita is realising that one is Brahman. This realisation is not just bookish knowledge. It is about how one interacts with the world. In Dvaita, one attains mokṣa when one reaches the abode of God. Dvaita claims that one cannot merge or become one with Brahman. This is because the jiva's soul is different from Brahman.

All interpretations of Vedānta are based on the showing that one's true self is not the body or the mind. To explain this line of thought, these writings introduce different concepts including

- the five body sheaths or the Pañcakosha, [21],

- the three types of bodies or śarīras, [24],

- mithyā which is loosely translated as illusion or what is unreal,

- sat which is the opposite of mithyā and thus loosely translated as real,

- anirvacaniya or the one that cannot be described because of limitations in language and

- the Neti-Neti (or apophatic) style of reasoning, [28].

While the above ideas are developed at length using natural language, they are still subject to different interpretations. In this article, we describe a 
formalism that can, in principle, capture the semantics of all these different concepts. This is based using a labelled transition system, [20, 12], and modal logic related, [10]. The process formalism used here can describe a variety of state based dynamic behaviours based on changes to the current state. This formalism can also be used to describe concurrent behaviours. While we do not focus on concurrency in this article, it is important that concurrency can be supported. Concurrency is needed to define how different entities evolve independent of each other as well how different entities can interact together.

The main purpose of the formalisation is to present a framework where all the key concepts from Vedānta can be well defined. The intention is that the formalisation will provide the basis for further discussions including distinguishing the different interpretations of the same concept. The usefulness of the formalisation is illustrated via a number of simple examples. These examples are not necessarily complete, in that they do not completely describe all the concepts in Vedānta and associated texts. They only illustrate the use of formalism to describe the key points of some of the concepts. They also show how the formal descriptions can be used to characterise the different interpretations of Vedānta or comparing Vedānta with other schools of thought, [19]. But such a comparison is beyond the scope of this paper. Similarly, we do not focus on the logical aspects present in Vedānta-related epistemology or concrete reasoning systems (such as Nyāya, [7]). Such descriptions can be found elsewhere, e.g., [5].

In short, the aim of the paper is to give a formal semantics to ideas from Vedānta. Towards this we use the idea of transition systems and logic of knowledge that are common in computer science. The key aspects of the formalism are first described in Section 2; the examples that use the formal notation are described in Section 3. Based on the examples in Section 3, a high-level system view is presented in Section 4.

\section{Formalisation}

In this section we explain the notation that underpins the formalism used to describe the key concepts. The formalisation is based on the following building blocks.

- An infinite set of states $\mathbb{S}$ with a distinguished element called $B$. Here $B \in \mathbb{S}$ represents Brahman.

- This set of states is partitioned into many subsets. That is, the in- 
tersection of each distinct subsets is empty. Each subset is typically written as $S_{j}$ for a particular entity $j$. For example, $j$ cane be a jiva which will be expanded in Section 3.1. Therefore, for different entities $j_{1}$ and $j_{2}, \mathbb{S}_{j_{1}} \cap \mathbb{S}_{j_{2}}=\emptyset$.

- An infinite set of actions $\mathbb{A}$ that represents the actions that can be performed.

- An infinite set of properties $\mathbb{P}$ that can be associated with each state except $B$. A number of properties may hold in any given state. Thus the set of properties for any given state will be a subset of $\mathbb{P}$.

Some of the descriptions in Vedānta are in terms of knowledge. That is, Vedānta outlines what can be known, who can know what, etc. Here we focus on subset of the techniques outlined in the book, [10]. For the purposes of this article, we define a binary relation $\mathbb{K}$ to represent knowledge. Elements of this relation belong to $\mathbb{P}$. So we can describe what is known and by whom in any given state. For instance, if $\mathbb{K}(a, b)(s)$ holds in a given state, we can conclude that entity $a$ knows $b$ in state $s$. We can also have $\mathbb{K}(a, \mathbb{K}(b, c))(s)$ which indicates whether $a$ knows that $b$ knows $c$ in state $s$. As per the Drg-Dṛ́sya-Viveka, [23], we cannot have $\mathbb{K}(o, o)$ as the object is different from the knower of the object. But we can have a chain of knowledge relations. For example, $\mathbb{K}\left(o_{2}, o_{1}\right), \mathbb{K}\left(o_{3}, o_{2}\right)$, and $\mathbb{K}\left(o_{4}, o_{3}\right)$ are all possible knowledge relations. That is, $o_{2}$ knows $o_{1}, o_{3}$ knows $o_{2}$ and $o_{4}$ knows $o_{3}$. So an object can know other objects but not itself. Disallowing self-reference prevents logical inconsistencies.

- As everything other than Brahman changes, it is natural to capture change as transitions between states. So we define a set of transitions as pairs of states labelled with action(s). This is written as $s \stackrel{a}{\longrightarrow} s^{\prime}$ where $a \in \mathbb{A}$. This indicates that one can move from state $s$ to state $s^{\prime}$ by performing action $a$.

Sometimes (mainly for notational convenience) we write $s \stackrel{\phi}{\longrightarrow} s^{\prime}$ where $\phi$ represents the change in properties as a result of performing some action $a$. Here the focus is not on the action but on the change in properties corresponding with the change in state. Thus $\phi \subseteq \mathbb{P}$.

- We use $B$ as the initial state for the transition system. This will be used to capture the fact that everything starts with Brahman. This indicates that without Brahman nothing can exist. 
The above formalism suffices for the main concepts we wish to illustrate via examples. The generality of this formalism has been illustrated in other research where different types of systems are described. The formalism presented in this article is more concrete than the other characterisations of Vedānta. For instance, the logic we are using here is relatively simple. More complex modal logics (e.g., [27]) can be incorporated in this framework without major effort. Similarly, [8] uses axiomatic set theory to define consciousness (an important aspect of Vedānta) but does not handle state transitions that occur in the material universe. State-based systems can be used to describe consciousness, [13].

\section{Examples}

In this section we present a few examples to illustrate some of the concepts developed in Vedānta. The examples presented here are chosen to cover a number of diverse topics to illustrate the generality of the approach.

\subsection{Brahman and Jiva}

Vedānta states that everything exists because of Brahman. This is captured by the requirement that for every state $s$, one can find a path from $B$ to $s$. As $B$ is the initial state nothing in the system can be obtained without Brahman $B$. This formalism answers the question what was there before Brahman. As Brahman is the initial state, the question of having something before Brahman does not arise. Otherwise, the entity before Brahman would be the initial state.

Furthermore, Brahman cannot be known and has no properties. This means that in all states $s$ and for all entities $e$ including $B$, we have $\neg \mathbb{K}(e, B)(s)$ and $\neg \mathbb{K}(e, \mathbb{K})$. That is, Brahman cannot know Brahman and it is not possible to know the relation $\mathbb{K}$. These requirements are added to avoid potential logical contradictions. The fact that Brahman has no properties holds by definition.

The next idea we consider is that of jiva or soul that has not attained mokșa or salvation as it captures the idea of living entities in this world. The reason for dividing the set of states into a set of disjoint states is that each subset represents the behaviour associated with a particular jiva. Formally, for each jiva (say $j$ ), we can identify a set of states $\mathbb{S}_{j} \subset \mathbb{S}$ and as described earlier for different jivas $j_{1}$ and $j_{2}$ the $\mathbb{S}_{j_{1}} \cap \mathbb{S}_{j_{2}}=\emptyset$. These properties state that the evolution of each jiva occurs within its own state space. Every jiva can interact with other jivas and this is illustrated in Section 3.4. 
Every jiva that is alive has a sthūla (gross), sūkṣma (subtle) and kāraṇa (causal) śarīra (bodies), [24]. To capture this, we define properties called 'hasSthūla', 'hasSūkṣma' and 'hasKāraṇa'. Formally, \{hasSthūla, hasSūkṣma, haskāraṇa $\} \subset \mathbb{P}$.

These properties are associated with the layers of the jiva and can be used to characterise, being embodied and death. In any state where all three properties hold, the jiva is said to be embodied. When the body dies, the sthūla śarīra ceases to exist. Thus death is characterised where 'hasSthūla' does not hold but 'hasSūkṣma' and 'hasKāraṇa' hold. Formally, death can be an abbreviation for the formula ' $\neg$ hasSthūla $\wedge$ hasSūkṣma $\wedge$ hasKāraṇa'.

These three properties can also be used to characterise pralaya or dissolution of the universe. When pralaya occurs, all jīvas have only their kāraṇa śarīra. Both the sthūla śarīra and the sūkṣma śarīra cease to exist. So a state $s$ can be said to represent pralaya when for all jivas the property ' $\neg$ hasSthūla $\wedge \neg$ hasSūkṣma $\wedge$ hasKāraṇa' holds.

The properties associated with the śarīras allow us to impose consistency checks. For example, if 'hasSthūla' holds, then both 'hasSūkșma' and 'hasKāraṇa' need to hold. Similarly, if 'hasSūkṣma' holds, then 'hasKāraṇa' has to hold.

Given this characterisation of a jiva, reincarnation is now a sequence of transitions from a state where the property associated with death holds to a state where the jīva acquires a new body, i.e., a sthūla śarīra. Consider the sequence of transitions $s_{1} \stackrel{\text { death }}{\longrightarrow} s_{2} \stackrel{\text { born }}{\longrightarrow} s_{3}$. Here $s_{1}$ and $s_{3}$ will belong to the same state partition associated with a specific jiva. In states $s_{1}$ and $s_{3}$ the property 'hasSthūla' holds while in state $s_{2}$ the property 'hasSthūla' will not hold. It is not essential for states $s_{1}$ and $s_{3}$ to be identical. The difference in $s_{1}$ and $s_{3}$ could be due to the change in karma (see Section 3.3) that is associated with those states.

\subsection{Free Will}

In some theories, God acts as a controller also called antarāmī. But this does not necessarily mean that all the jivas have a pre-determined life. The jivas have free will. God's role in free will can be defined in terms of the set of transitions that are available at each state. That is, the set of transitions represents the options one has at any given point. Each jiva can choose one of these options based on its current tendencies, thinking etc. capturing the semantics of free will. That is, free will is having choice to select possible behaviours at any given state.

An example is shown in Figure 1. Assume that in state $s_{1}$ three choices 
are possible. God might decide, for whatever reason, that in this state the option to perform $b_{1}$ should not permitted. Thus the jiva still has choice to perform either action $a_{1}$ or $c_{1}$ but state $s_{3}$ is not reachable from $s_{1}$. If the jiva chooses $a_{1}$, the states $s_{5}, s_{8}$ and $s_{9}$ are potentially reachable. That is, God is not constraining any behaviour from $s_{2}$ and $s_{5}$. However, if the jiva chooses $c_{1}$, the only possible move is to state $s_{6}$ via action $c_{2}$ because action $c_{3}$ is blocked by God.

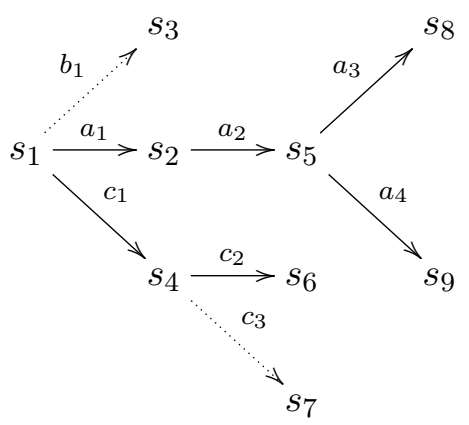

Figure 1: Free Will

The example shows that behaviour of the jīva is not pre-ordained. Both God, via making options available, and the jiva's free will by choosing the option that is made available have a role in deciding what happens in the future.

Such control of behaviour could occur via assigning specific karma values (developed in Section 3.3) to each state. So one's past or current karma could enable or disable certain transitions. Therefore, the value associated with karma can be used to encode either the enabling or inhibition of certain actions.

Overall, God or karma act as controller (as in discrete control systems, [26]) where certain actions are disabled while all the jivas are like the environment in system theory. That is, the behaviour of all the jivas is unpredictable as they have free will. They are free to choose from the available list of actions. But unlike a safe controller, not all unsafe behaviours are necessarily blocked by God. The chosen behaviour, be it good or bad, is left to the individual.

To capture this formally, we define a class of properties 'godAllows $(\alpha)$ ' for every action $\alpha$ (i.e., $\alpha \in \mathbb{A}$ ). This can be used to describe aspects of the transition system in Figure 1 as follows.

In state $s_{1}$ the property ' $\operatorname{godAllows}\left(a_{1}\right) \wedge \operatorname{godAllows}\left(c_{1}\right) \wedge \neg \operatorname{godAllows}\left(b_{1}\right)$ ' 
holds.

In state $s_{4}$ the property ' $\operatorname{godAllows}\left(c_{2}\right) \wedge \neg \operatorname{godAllows}\left(c_{3}\right)$ ' holds.

In state $s_{5}$ the property ' $\operatorname{godAllows}\left(a_{3}\right) \wedge \operatorname{godAllows}\left(a_{4}\right)$ ' holds.

\subsection{Karma and Mokșa}

Karma can also be encoded in this system as a specific class of property. Changes in karma are captured via changes in the set of properties between the starting and ending state. For example, let us assume for the sake of simplicity that the property of karma is denoted as a pair of integer values representing good and bad karma (i.e., $\langle g, b\rangle$ ). If one does a good action but it is not without dispassion the karma in the new state will be $\left\langle g^{\prime}, b^{\prime}\right\rangle$ where $g^{\prime}>g$ and $b^{\prime} \leq b$. The usual understanding is that $b$ will not change but it is possible to have a theory where a good action offsets a part of past bad karma; hence $b$ can decrease. Similarly, a bad action will result in the value of $b$ increasing ( $g$ may or may not increase) and a dispassionate action will not change the karma.

Normally, mokșa occurs when one's accumulated karma is zero or $\langle 0,0\rangle$. Mokṣa at one level is simple and it occurs when the transition from a state to $B$ is taken. That is, one has reached the end goal of spirituality, namely, "being one with Brahman". Such a transition only occurs when the karma is $\langle 0,0\rangle$.

Such transitions are not sufficient as they do not handle the notion of jivvan mukta, [18]. A jivan mukta is one who has realised Brahman but is still living, i.e., has a body. A jīvan mukta can be represented as a state where all the three sarīra's exist and there is no karma (i.e., karma is $\langle 0,0\rangle$ ). To capture the semantics of jivan mukta, for all such states where they are alive, the only possible move is to a state where the body is dead and then both the sūkṣma śarīra and the kāraṇa śarīra disappear leading to Brahman.

Technically, we have to split karma into sañcita karma or the accumulated karma during this birth, prārabdha karma or the karma that is associated with one's birth and āgami karma that is the result of current actions. That is, we are refining the pair of integers can be split into 'sañcitaKarma', 'prārabdhaKarma' and āgamiKarma. This does not require any change in the basic framework. Only the encoding of karma has to change from a pair into three pairs. The above description of change in karma via current actions performed will apply only to the āgami karma. When we say a jivan mukta has no karma it applies only to the sañcita and āgami karma. The prārabdha karma will disappear only at the time of death. 
All transitions in the living world made by a jīvan mukta must keep the absence of sañcita and āgami karma invariant. That is, all transitions for a jivan mukta from a state where there is no sañcita karma has to be to a state where there is no sañcita karma. Some aspects of this is captured by the transitions shown in Figure 2. Here actions $a$ and $b$ are performed when the jivan mukta is living. Such an invariant applies only after the jiva has become a jivan mukta. Otherwise, the jiva will continue to accumulate sañcita karma.

Thus the property 'hasSthūla' holds in states $s_{1}, s_{2}$ and $s_{3}$. Also, 'sañcitaKarma $\left(s_{1}\right)=$ sañcitaKarma $\left(s_{2}\right)=$ sañcitaKarma $\left(s_{3}\right)$ ' and 'āgamiKarma $\left(s_{1}\right)=\overline{\text { agamiKarma }}\left(s_{2}\right)=\overline{\text { agamiKarma }}\left(s_{3}\right)^{\prime}$ ' are true. When the body associated with the jivan mukta dies, the jivvan mukta enters the state $s_{4}$ where 'hasSthūla' does not hold. Now the only possible transition is to Brahman. This transition is called videha mukti in the literature (i.e., mukti achieved without a body or moksa after death). The absence of any other transition is shown using $\times$. Formally, videha mukti occurs in state (say $s_{4}$ ) where $\neg \exists s_{5} \neq B, a:\left(s_{4} \stackrel{a}{\longrightarrow} s_{5}\right)$. That is, there is no action or state (other than Brahman) that the state $s_{4}$ can evolve to.

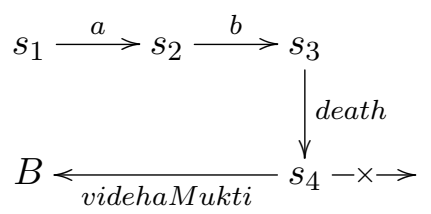

Figure 2: Jivan Mukta

\subsection{Interaction with Others and Joint Behaviour}

Thus far we have outlined the behaviour of a particular jiva without any reference to other jivas. In reality, each jiva interacts with other jivas. To capture this, we define an interaction relation which will contain all possible interactions. This requires an extension to the basic formalisation which considered each state transition in isolation.

Formally, interaction is represented by a set $\mathbb{I}$. This can be formally defined in terms of subsets of the relation $\longrightarrow$. Each interaction is a set of transitions from different jivas. For example, the set $\left\{s \stackrel{\alpha}{\longrightarrow} s^{\prime}, t \stackrel{\beta}{\longrightarrow} t^{\prime}, u \stackrel{\gamma}{\longrightarrow}\right.$ $\left.u^{\prime}\right\}$ represents an interaction between three jivas. It describes the situation where the jivas in states $s, t, u$ interact with each other and move to the states $s^{\prime}, t^{\prime}, u^{\prime}$ respectively. The actions $\alpha, \beta$, and $\gamma$ need to be performed by the 
individual jivas for the interaction to occur. We can impose a consistency requirement on elements in $\mathbb{I}$. We require that the partitions that contains $s, t$ and $u$ respectively are all mutually disjoint. That is, interaction occurs only between different jivas. So $s, t$ and $u$ have to belong to sets associated with three distinct jīvas.

We now give a simple example that uses the above formalism. The example describes the incident from the Mahābhārata where Bhīma hits Duryodhana's thighs. This can be seen as an interaction between Bhima, Duryodhana, Sanjaya (who was narrating the incident) and Dhṛtarāṣtra (who was listening to Sanjaya). This can be represented by the following four transitions operating together.

Bhīma: $b \stackrel{\text { hit }}{\longrightarrow} b^{\prime}$ where hit represents hitting Duryodhana's thighs

Duryodhana: $d u \stackrel{\text { gotHit }}{\longrightarrow} d u^{\prime}$ where gotHit represents getting hit on the thighs by Bhīma

Sanjaya: $s \stackrel{\text { describe }}{\longrightarrow} s^{\prime}$ where describe is Sanjaya narrating the incident and

Dhṛtarāṣtra: $d h^{\text {emotions }} \stackrel{d h^{\prime}}{\longrightarrow}$ where the action emotions represents both feeling sad at Duryodhana's plight and feeling angry at the Pandavas. That is, the state $d h^{\prime}$ associated with Dhrtarāṣtra denotes him feeling sad at the impending loss of his son, Duryodhana, and also angry at the Pandavas for inflicting damage to his children.

Without explicitly considering interaction, one can state that hit and gotHit have to occur in the same step. Other than this notion of "simultaneity", none of the previous descriptions, say related to properties such as karma need to change. One only needs to define what is the outcome of the joint behaviour. While joint behaviours requires the participation of multiple jivas, the outcome for each jiva in terms of the resulting state is defined individually. Therefore, the idea of associating properties with states needs no change. For example, if aspects of the interaction are unethical, the performers' negative karma will increase and the karma of the one who suffered could reduce. Specifically, the result of this interaction could be the following.

- Bhìma accumulates some negative karma (for violating the rules of war). This change in karma will be reflected in the property associated with the state $b^{\prime}$ 
- Duryodhana who has become mortally wounded, has undergone suffering and will have some reduction in his negative karma. As he is not yet dead, he still has his sthūla śarīra. Similar to $b^{\prime}$, the change in Duryodhana's karma will be reflected in the property associated with $d u^{\prime}$.

- Dhṛtarāsțra has also suffered and his negative karma will be reduced. The reduction would depend on the level of mental anguish offset with his emotions desiring revenge.

- As Sanjaya is just an observer and is not affected by the above actions, there will be no change in karma for Sanjaya.

\subsection{Aspects from the Yoga Sūtras}

Patañjali's yoga sūtras, [3], have had a huge impact on Vedantic thinking especially the ideas related to meditation and controlling the mind. In this section we describe two related concepts from the yoga sūtras. The first is a wandering mind, where in a given state one cannot focus and the second is a calm mind which is not affected by the behaviour of others.

To describe a wandering mind, we first define a set of actions (say $T \subseteq \mathbb{A}$ ) to represent one's thoughts. A mind is wandering in a given state (say $s$ ) when different actions from $T$ lead to different states. For example, let $a$ and $b$ belong to $T$, and $s \stackrel{a}{\longrightarrow} s_{a}$ and $s \stackrel{b}{\longrightarrow} s_{b}$ be the two possible transitions where $s_{a}$ and $s_{b}$ are different states. If the mind is focussed on only one thought (say on $a$ ), the transition $s \stackrel{b}{\longrightarrow} s_{b}$ will not be taken. Otherwise in state $s$, the mind is wondering which action ( $a$ or $b$ ) to perform.

In a way, this is related to free will. That is, certain transitions will not occur. In the case of a focussed mind, the control in terms of which transitions are generated (i.e., elements of $T$ ) and which are not taken is exercised by the jiva. Here, unlike in the case of free will, God has no role.

In general one's mind is less wandering in state $s_{1}$ than in state $s_{2}$ if the cardinality of the set $\left\{s_{a} \mid s_{1} \stackrel{a}{\longrightarrow} s_{a}, a \in T\right\}$ is less than the cardinality of the $\left\{s_{a} \mid s_{2} \stackrel{a}{\longrightarrow} s_{a}, a \in T\right\}$. That is from $s_{1}$ there are fewer options than from $s_{2}$. Because the number of possible choices the mind has to consider (i.e., actions from $T$ ) in state $s_{1}$ is less than the number of possible choices in state $s_{2}$, one can conclude that the mind in state $s_{1}$ is not wandering as much as from $s_{2}$. An transition of form $s_{1} \stackrel{a}{\longrightarrow} s_{1}$ indicates that the action $a$ has no effect on $s_{1}$ and also represents a non-wandering mind, for the action $a$. Here the thought $a$ occurs but has not change the jiva's state. 
In the above formalisation, the set of actions in $T$ are atomic. We can enhance $T$ with actions that represent the thought arising, the thought being extinguished as well as actually performing the action that arose. This only increases the granularity of the possible transition system.

Towards defining a calm mind, we consider transitions in II because we wish to measure the effect of external effects on one's mind. One's mind is calm in state $s_{1}$ with respect to a particular thought $a \in T$ when for every set $I$ in $\mathbb{I}$, there is only state $s_{2}$ where $s_{1} \stackrel{a}{\longrightarrow} s_{2}$ irrespective of the other elements in $I$. That is, the behaviours of other entities have no effect on the behaviour from the state $s_{1}$. This definition allows change from state $s_{1}$; but that would be based purely on the thought process of the jiva associated with state $s_{1}$.

As an example consider the two interactions $\left\{s \stackrel{a}{\longrightarrow} s_{1}, t \stackrel{b}{\longrightarrow} t_{1}\right\}$ and $\left\{s \stackrel{a}{\longrightarrow} s_{2}, u \stackrel{c}{\longrightarrow} u_{1}\right\}$ where $s_{1} \neq s_{2}$. Here the jiva's behaviour in state $s$ on the action $a$ is influenced by the actions $b$ or $c$ resulting in different consequences. Such a behaviour represents a mind that is not calm. The mind is reacting to what others are doing ( $b$ or $c$ in this case). However, if $s_{1}$ and $s_{2}$ were identical, the mind can be said to be calm in this particular situation as it effectively ignores the influence actions $b$ and $c$.

The above definition of a calm mind can also be used to define Kṣhānti (forbearance) where one is equipoised in all circumstances, [14]. That is, the behaviour (i.e., transition) chosen by people exhibiting Kṣhānti will not depend on the action of the others around them.

\subsection{Dream State and Entities in a Dream}

The Māṇụ̄kya Upaniṣad, [22], discusses how the three Avasthās of waking, dreaming and deep sleep are all different from Brahman. Here we show how the basic structure of the set of states and knowledge can be used to capture the intended semantics in the Māṇ̣̄ukya Upaniṣad.

Given a jiva $j$, the set of states associated with it (i.e., $\mathbb{S}_{j}$ ) can be further divided into $\mathbb{S}_{j}^{D}$ and $\mathbb{S}_{j}^{A}$ to represent the states in the dreaming and the waking world respectively. A person starting to dream is captured by the state transition $s_{1} \stackrel{\text { dream }}{\longrightarrow} s_{2}$ where $s_{1} \in \mathbb{S}_{j}^{A}$ and $s_{2} \in \mathbb{S}_{j}^{D}$. As dreaming can occur only when the jiva has a body, the property 'hasSthūla' needs to hold in both state $s_{1}$ and $s_{2}$.

In a dream state, the entities dreamt by the jiva $j$ belong solely to $j$ 's space. Thus whenever $\mathbb{K}(j, o)(s)$ holds where $s \in \mathbb{S}_{j}^{D}$, the object $o$ has to belong to $j$ 's state space. It is possible that $o$ may correspond to an object in some other's jiva's state but it itself has belong to $j$ 's state space. 
For example, one may dream about Kṛ̣ṇa teaching Arjuna but the Kṛ̣ṇa and Arjuna are in the dreamer's state and are not the "real" Kṛṣna and Arjuna. The Kṛ̣na in the dream corresponds to the real Kṛ̣na but is not the real Kṛ̣na. So in state $s$ where jiva $j$ is dreaming, we have $\mathbb{K}(j, \operatorname{teach}(k, a))$ where the predicate teach $(k, a)$ indicates Kṛ̣na is teaching Arjuna. But $k$ and $a$ are not the same as Krṣna and Arjuna and neither are $k$ and $a$ some random entities. The Kṛ̣na and Arjuna in the dream do have a link to the real Kṛṣna and Arjuna.

To capture the relation between the entities in the dream state and in the real world, we define a map that links Kṛ̣na with $k$ and Arjuna with $a$. Formally, this map contains elements of the form $\left(a, d_{a}^{j}\right)$ where $a$ is an entity and $d_{a}^{j}$ is $a$ 's appearance in $j$ 's dream. So if, $K$ and $A$ represent the real Kṛṣna and Arjuna, we will have $\left(K, d_{K}^{j}\right)$ and $\left(A, d_{A}^{j}\right)$. That is, $k$, the real Kṛ̣na is mapped to $d_{K}^{j}$ the Kṛṣna in the dream and $a$, the real Arjuna, is mapped to $d_{A}^{j}$ the Arjuna in the dream.

The linking of state transitions and knowledge-based predicates using the above example is illustrated below. Consider the following sequence of state transitions for an individual jiva $j$.

$s_{1} \stackrel{\text { dream }}{\longrightarrow} s_{2}$ representing $j$ starts dreaming,

$s_{2} \stackrel{\text { teachingInDream }}{\longrightarrow} s_{3}$ where $j$ starts dreaming about Kṛṣna teaching Arjuna

$s_{3} \stackrel{\text { awake }}{\longrightarrow} s_{4}$ and $j$ wakes up.

In state $s_{3}$ we can state that $\mathbb{K}(j$,teach $(k, a))$ holds while in $s_{4} \mathbb{K}(j$,teach $(k, a))$ will not hold. However if the person knows that Kṛṣna taught the Gitā to Arjuna, the knowledge formula $\mathbb{K}(j, \operatorname{teach}(K, A))$ will hold. in states $s_{1}$ and $s_{4}$.

Another simple example, is when a person (say jīva $j$ ) dreams about achieving something. The person dreaming $(j)$ and the person in the dream $\left(d_{j}^{j}\right.$, i.e., $j$ is dreaming about $j$ ) are clearly not the same but are related. Thus $j$ will be mapped to $d_{j}^{j}$.

This concludes the description of the various examples. In the next section, we will put some of these ideas together to construct a big-picture system view.

\section{System View}

Thus far we have looked at individual concepts that are used to explain the different metaphysical concepts in Vedānta. We now present a high- 
level system view without all the internal details of the individual systems. Figure 3 has a simple depiction of how the universe arises from Brahman, and an abstract semantics for samsāra, pralaya and mokṣa. The system has a potential unending cycle because after pralaya there is a re-creation of the universe. Figure 3 does not indicate how many times the cycle of samsāra is taken. The exact number of iterations would depend on the specific values of karma and the actions that update it. Thus the karma shown in the diagram is not a specific value. It represents the presence of karma for all concrete states associated with the jiva. So, this general description needs be instantiated for each particular situation, to explain how an individual's life unfolds.

The transition labelled mokṣa leading to Brahman is technically valid only in Advaita. Also, it does not capture the behaviour of a jīvan mukta. Similarly, the label of māyā on the transition from Brahman to the universe is also specific to Advaita. A dashed arrow is show from Brahman to the universe to illustrate that the state "Brahman" does not change. So the transition does not represent an evolution of Brahman's state. Formally, this can also be represented by asserting that Brahman exists at each and every state.

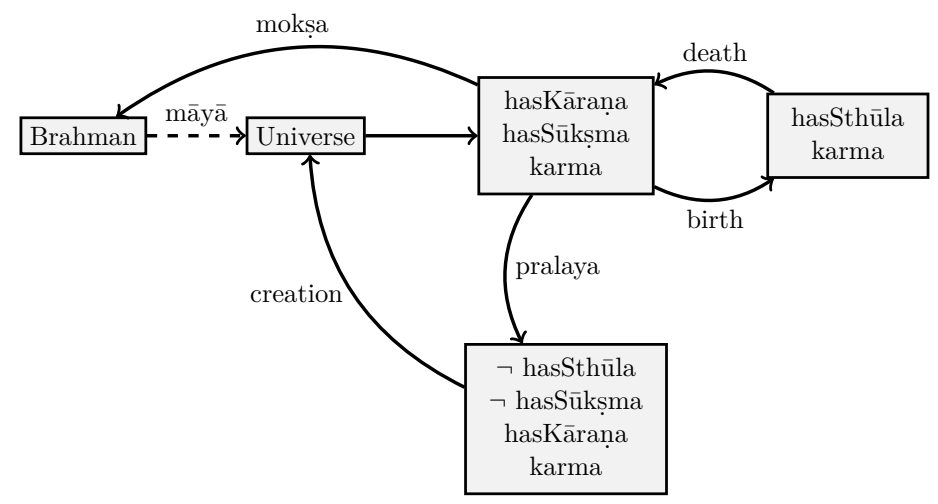

Figure 3: System Behaviour: Advaita

The transition system in Figure 3 can be interpreted as giving a precise semantics for the mahāvākyas, [15] that appear in the different Upaniṣads. For example, the statement "Tat Tvam Asi" (or Thou are That) can be stated as follows. For each jiva $j$ that corresponds to "Thou" in any state $s$, we can always find a path from $s$ that leads to Brahman. So in our formalism we do not equate the true self of any jiva with Brahman. It is about the 
possible evolution of behaviour that can eventually reach Brahman. Thus the semantics of the mahāvākya in our system is that all jivas can reach Brahman.

The statement "Prajñānam Brahma" requires a more careful analysis. The statement is not about any jiva. Hence it is not directly related to the transition system. As the statement is about knowledge, the semantic characterisation of Brahman is the relation $\mathbb{K}$. This relation can be associated with Brahman because Brahman cannot be known in the conventional way but "knows" everything. All other states will have some item that is not known. That is, for every state $s \neq B$, there exists a formula $\mathbb{K}(i, o)$ such that $\mathbb{K}(i, o)$ does not hold at $s$. That is, entity $i$ does not know object $o$ in state $s$. We axiomatically equate Brahman $B$ with $\mathbb{K}$. We do not wish to state that $B$ knows everything as that could lead to logical contradictions.

The dvaita view is captured in Figure 4. Firstly, mokșa is reaching Brahman's or Vishnu's abode (Vaikuntha) and not merging with Brahman. The relationship between Vishnu and Vaikunthha is captured by the transition labelled "lives" to indicate Vishnu lives in Vaikunthha. In dvaita, grace of God is important. Hence apart from karma, we include a new predicate called 'getsGrace'. Dvaita does not believe in māyā but has a notion of līlā (God's non-selfish play). Therefore, the transition (again shown as a dashed line to show that Brahman does not change) from Brahman or Vishnu is now labelled līlā. Here again, each jīva has a sequence of transitions that lead to Vaikunțha.

Apart from identifying the difference in the definition of mokșa, the formalism identifies what is common to advaita and dvaita. For instance, concepts such as sthūla śarīra and pralaya are not affected by the different interpretations of mokșa.

\section{Conclusion}

In summary, this article has illustrated how many aspects of Hindu philosophy, viz., Vedānta can be captured in a mathematical framework. The key contributions are

- A set of states $(\mathbb{S})$ that can be partitioned for each jiva and within the states for the jiva it can be divided into dreaming and waking states. A map that can captures the correspondence between entities and their occurrences in people's dreams.

- A set of properties $(\mathbb{P})$ that can be used to describe the properties that 


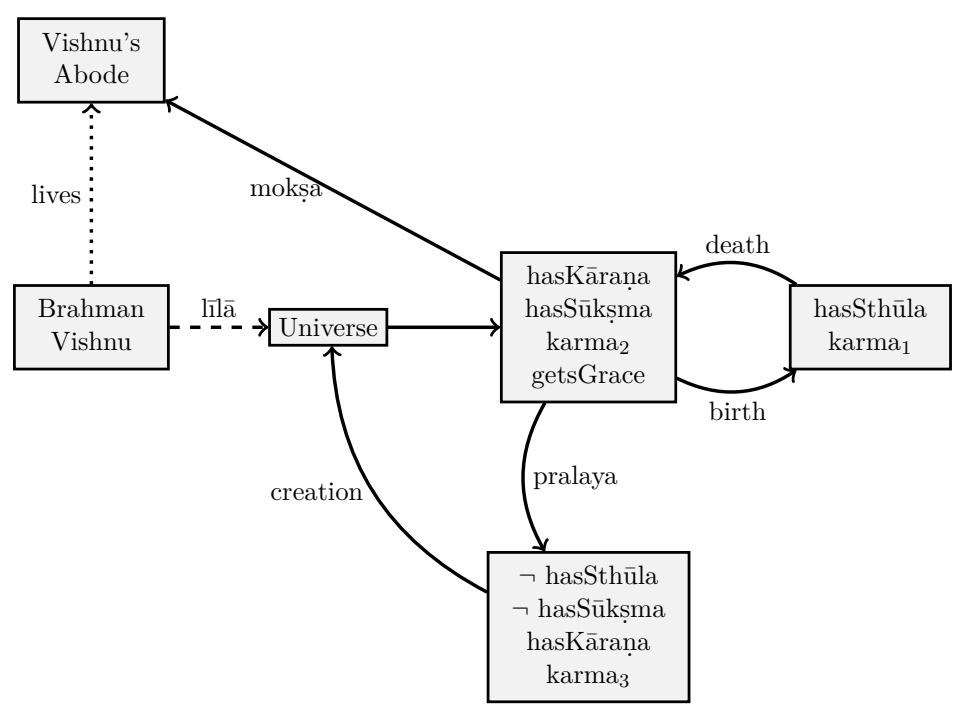

Figure 4: System Behaviour: Dvaita

hold at each state. This can be used to encode a variety of concepts including the sarīras and karma. The different śarīras are represented by simple predicates while karma is represented either as a simple pair of integers or as a pair of pair of integer values to capture sañcita karma and prārabdha karma. The notion of knowledge $(\mathbb{K})$ can also be associated with states to indicate what is known in each state.

- A set of transitions $(\longrightarrow)$ between states to capture behaviour. Transitions combined with properties such as ' $\operatorname{godAllows}(\alpha)$ ' for specific actions, enables the description of the role of God in free will for the jivas. The transition system can also be used to define a jivan mukta and when videha mukti can occur.

- A set of interactions (II) which are nothing but sets of transitions to capture joint behaviour. This is necessary as the jivas interact with each other in this world. It is also useful to define the influence of others on a particular jiva and how that jiva reacts to this external influence. This set of possible interactions is used to identify a calm mind.

- Various examples (e.g., free will, aspects from the yoga sūtras, mokṣa) to illustrate the usefulness of the formalism. 
The formalism presented here can be used to describe concepts such as consciousness, [11]. The formalism can also be extended to cover probabilistic behaviours and notions of information to accommodate other descriptions of consciousness, [30]. Potential future work is to develop a deep semantics for specific concepts in Vedānta.

\section{Acknowledgements}

Many thanks to Lakshmi Narasimhan for her comments on an initial version of the paper.

\section{References}

[1] Swami Abhedananda. An introduction to the philosophy of the Panchadashi, 1948.

[2] A. A. Ansari. The Ethical Philosophy of Yoga Vasishtha. PhD thesis, Aligarh Muslim University, 2008.

[3] Sri Aurobindo. Bases of Yoga. Sri Aurobindo Ashram Trust, 1981.

[4] Sri Aurobindo. Kena and Other Upanishads. Sri Aurobindo Ashram Trust, 2001.

[5] P. Balcerowicz. Is there anything like Indian Logic? Anumana, 'inference' and inference in the critique of Jayarasi Bhatta. Journal of Indian Philosophy, 47:917-946, 2019.

[6] A. Barua. The absolute of advaita and the spirit of Hegel: Situating Vedanta on the horizons of British idealisms. Journal of Indian Council of Philosophical Reearch, 34:1-17, 2021.

[7] J. Burton. Diagrams from Navya-Nyaya. Journal of Indian Philosophy, 48:229-254, 2020.

[8] P. Corazza. Mathematics of pure consciousness. International Journal of Mathematics and Consciousness, 2014.

[9] E. Easwaran. The Upanishads. Nilgiri Press, 2018.

[10] R. Fagin, J. Y. Halpern, Y. Moses, and M. Vardi. Reasoning About Knowledge. MIT Press, 2004. 
[11] L. Floridi. Consciousness, agents and the knowledge game. Minds and Machines, 2005.

[12] R. Gorrieri. Labeled transition systems. In Process Algebras for Petri Nets, 2017.

[13] P Grindrod. On human consciousness: A mathematical perspective. Network Neuroscience, pages 23-40, 2017.

[14] V. Lele. Yoga of Gita Expounded by Saint Dnyaneshwar: Inner Secrets of Raja Yoga. Yogeshwar Kutir Publication Vrindavan Dham, 2015.

[15] J. MacPhail. The great sayings of Vedanta, integral style: Vivekananda's iterpretation of the Mahavakyas, 2010. Lecture to Postgraduate Students.

[16] J. Madaio. Liberation and Hindu studies. The Journal of Hindu Studies, 12:1-11, 2019.

[17] Swami Madhavananda. Vivekachudamani of Sri Sankaracharya. Advaita Ashram, 1921.

[18] G. R. Malkani. A note on liberation in bodily existence. Philosophy East and West, 5:69-73, 1955.

[19] J. Milne. Advaita vedanta and typologies of multiplicity and unity: An interpretation of nondual knowledge. International Journal of Hindu Studies, 1997.

[20] Robin Milner. A Calculus of Communicating Systems. Springer Verlag, 1980.

[21] Y. Mishra. Critical analysis of Panchakosha theory of Yoga philosophy. World Journal of Pharmaceutical Research, 8, 2019.

[22] Swami Nikhilanand. Mandukya Upanishad With Gaudapada's Karika and Shankara's Commentary. Advaita Ashram, 2006.

[23] Swami Nikhilananda. Drg-Drśya-Viveka: An Inquiry Into the Nature of the Seer and the Seen. Sri Ramakrishna Asrama, 1931.

[24] Swami Nikhilananda. Self-Knowledge: Sankaracharya's Atma Bodha. Sri Ramakrishna Math, 1947. 
[25] S. Radhakrishnan. The Principal Upanishads. Indus/Harper Collins, 2016.

[26] P. J. Ramadge and W. M. Wonham. Supervisory control of a class of discrete event processes. SIAM Journal on Control and Optimization, 25:206-230, 1987.

[27] A. Schumann. Nagarjunian-Yogacarian modal logic versus Aristotelian modal logic. Journal of Indian Philosophy, 49:467-498, 2021.

[28] A. Sharma. Neti Neti and via negativa in Hindu thought. Prudentia, 1981.

[29] A. Sharma. Philosophical notes on the dark Yajur Veda:The findings of sage Bhrigu, 2015.

[30] G. Tononi, M. Boly, M. Massimini, and C. Koch. Integrated information theory: From consciousness to its physical substrate. Nature Reviews Neuroscience, 17, 2016.

[31] R. Waxman. Vedanta Hinduism: The Path to Transcendence, 2018. 